\title{
Accountability in the Shadow of Hierarchy: The Horizontal Accountability of Agencies
}

\author{
Thomas Schillemans
}

Published online: 4 July 2008

(C) The Author(s) 2008

\begin{abstract}
In the Netherlands, new accountability arrangements are created as remedies for the accountability deficit of agencies. These arrangements are of a 'horizontal' nature, as the agencies account for their behaviour towards accountees that are not their hierarchical superiors: clients, stakeholders or peers. This paper provides an inventory and qualitative assessment of horizontal accountability arrangements. It is argued that they have added value because they stimulate learning. However, horizontal accountability is not a substitute for hierarchical accountability. Horizontal accountability arrangements operate 'in the shadow of hierarchy': they gain significance through complex interactions with traditional forms of accountability.
\end{abstract}

Keywords Agencies Accountability - Accountability deficit · Horizontal accountability $\cdot$ Shadow of hierarchy $\cdot$ Learning

In recent years, many public service organizations have been granted substantial autonomy (see Van Thiel 2000; Thatcher and Stone Sweet 2002; Pollitt et al 2004). The creation of agencies at arms length has caused widespread concern regarding their accountability. Their partial autonomy limits the possibilities for ministerial control. This has resulted in a much diagnosed 'accountability deficit' of arms-length governance (see Van Thiel 2000: 167; Flinders 2001: 41; Mulgan 2003: 74; Pollitt 2003).

One of the possible remedies is to create new forms of accountability that complement traditional, hierarchical accountability (see Barberis 1998; Braithwaite 1999, Flinders 2001). These forms of accountability are often of a 'horizontal' nature (Scott 2000; Mulgan 2003; Bovens 2005). The adjective, horizontal, indicates an important distinction from traditional forms of accountability, where a subordinate

T. Schillemans $(\bowtie)$

Public Administration, Utrecht School of Governance (Utrecht University), Bijlhouwerstraat 6, 3511 ZC, Utrecht, The Netherlands

e-mail: t.schillemans@uu.nl 
usually reports to a superior (hence these can be coined vertical forms of accountability). Horizontal accountability arrangements address peers, equals, stakeholders or concerns outside of the hierarchal relationship between central government and executive agency.

Horizontal accountability is said to be a promising solution for the accountabilityproblems of agencies. The growth in size and complexity of present-day public administration has lead to a fragmented system of governance that is ill adapted to hierarchical, Weberian models of accountability. As Scott (2000: 42) notes: 'Constitutional lawyers almost universally agree that traditional accountability on its own has become inadequate in present day public administration'. Critics have called for an accountability regime that is more dispersed (Braithwaite 1999; Bovens 2005), features more mutual relations between accountors and accountees (Behn 2001; Roberts 2001) or relies on networks (Harlow and Rawlings 2007).

In the Netherlands, the more or less programmatic creation of agencies in the 1990's was accompanied by policy-efforts to balance the loss of governmental control with additional accountability arrangements. Important policy actors, such as the Home department, the National Court of Audit and the Scientific Council for Government policies, all underlined the importance of new and more horizontal forms of accountability (Schillemans 2007). As a result, new accountability arrangements have been created by many Dutch agencies.

This paper is concerned with an empirical analysis of a number of these new accountability arrangements. The introduction of horizontal accountability poses at least three empirical questions. The first question is what forms of horizontal accountability are on the rise? The second question is what they actually contribute to the accountability of agencies. This requires an empirical approach to the practices of horizontal accountability. Can they be considered as extensions of traditional accountability or do they have complementary contributions? And thirdly, how are we to understand the role of new arrangements in the accountability regime of agencies?

\section{Horizontal accountability}

In recent years, many authors have commented upon the complexity and manifold meanings of accountability (Dubnick 2005; Sinclair 1995; Bovens 2005). The academic literature features a variety of different conceptual approaches. However, at a basic level of analysis, many authors agree upon a minimal definition. This section will first provide a definition of accountability and then discuss under what conditions accountability is considered to be horizontal. This leads to a number of criteria that will be used to distinguish the horizontal accountability arrangements of Dutch agencies. Also, attention will be given to the expected added value of horizontal accountability.

Accountability defined

In a narrow sense, many authors understand accountability to be a communicative interaction between an accountor (person or organization) and an accountee (see Pollitt 
2003: 89), in which the former's behaviour (in the broadest sense of the word) is evaluated and judged by the latter, in light of possible consequences (c.f. Day and Klein 1987: 5; Romzek and Dubnick, 1998: 6; Scott 2000: 40; Mulgan 2003: 9). Accountability then requires an actor with a duty to render an account and a second actor with the authorization to judge and, usually, impose sanctions. In this sense, accountability refers to answerability to someone for appropriate conduct and expected performance. Accountability as it is understood here, refers to the processes by which actors provide reasons for their actions against the backdrop of possible negative (or positive) consequences (Dunn 1999: 335). Accountability implies that the accountor explains and justifies his behaviour towards a significant other (see Orbuch 1997: 455; Roberts 2001: 1551; Keohane 2002: 4; Dubnick 2005: 1).

The communicative interaction between accountor and accountee presupposes a relationship. This relationship often exhibits formal as well as informal elements. The accountee is usually in an authorized position to demand answers from the accountor. Accountability is first of all based on a formalized relationship that stipulates the rights, authorities and available sanctions of the accountee (see Broadbent et al 1996: 269; Aucoin and Heintzman 2000: 54). The accountee has the right to demand information, the duty to pass judgment and the opportunity to sanction dissatisfactory conduct. This formalized relationship distinguishes accountability from the many other communicative relations of public agents with other parties. In addition, however, there is usually also a subjective element to accountability. As different authors note, the accountor feels obliged to render an account of his conduct, behaviour and performance to the accountee (Lerner and Tetlock 1999: 255; McCandless 2001: 22). The accountor acknowledges the position of the accountee as his accountability-holder. In order to trace this subjective aspect of accountability, scholars have often asked people in public administration to indicate to whom they felt to be accountable (see Day and Klein 1987; Sinclair 1995; Romzek and Dubnick 1998; D. Dunn 1999; Verschuere et al. 2006).

From an analytical perspective, processes of accountability normally involve three phases (Mulgan 2003; Bovens 2005). In the first phase, the accountor renders an account on his conduct and performance to a significant other. This may be coined the information phase. In the second phase, accountor and accountee engage in a debate on this account. The accountee may ask for additional information and pass judgment on the behaviour of the accountor. The accountor will answer to questions and if necessary justify and defend his course of action. This is the debating phase. Finally, the accountee comes to a concluding judgment and decides whether and how to make use of available sanctions. This is the sanctions or consequences phase.

Sanctions may vary from formal disapproval to tightened regulations, fines, discharge of management or even the termination of the organization. Many authors notice that there is a hierarchy of sanctions. As Hood et al (1999: 47) indicate: 'It emanates with the 'ability to shame', escalates to lighter weapons such as certificates or formal (dis)approvals and culminates in the 'nuclear weapon' of liquidation'. From a legal and institutional design perspective it is imperative that the accountee has sufficient investigative and sanctioning powers. The literature on accountability often focuses on the 'heavier weapons' amongst the formal sanctions and the adoption of performance standards. This is enhanced by the fact that many authors favour a principal-agent approach to accountability, in which controlling the agent 
(=accountor) is a crucial concern (see Przeworski et al. 1999; Strøm 2000; Broadbent et al 1996; Besley and Ghatak 2003).

In addition to formal sanctions, informal consequences may also follow from accountability. This was already implicit in the above quote from Hood et al (1999): their hierarchy of sanctions started with 'the ability to shame'. Negative publicity may also be seen as a form of sanctioning, even though no formal retribution is used (see also Harlow and Rawlings 2007: 545). Accountability arrangements can be depicted on a scale, with strong mechanisms on the one extreme, where the accountee is armed with the 'nuclear weapon' of liquidation', and relatively weak mechanisms on the other extreme, where the accountee may only 'shame' the accountor in public, in front of his peers or before the eyes of a political principal.

It is not necessarily the case that stronger forms of accountability are more influential than weaker forms, even though this would be a logical assumption. As Braithwaite (1997) indicates: big sticks rebound. The application of heavy sanctions may have negative implications for the accountee, invoke defensive reactions and perverse effects, or, at the very least, put a strain on the relationship between accountor and accountee. Conversely, authors have noted that relatively weak mechanisms can sometimes have huge impacts on public organizations. One of the reasons is that the voice of a reputable accountee may damage the reputation of the accountor if it appears in public (see Smulovitz and Peruzzotti 2003: 6). The impact of negative voice depends on reputations and the saliency of the issue involved (see Lerner and Tetlock 1999: 258). Managers of public agencies therefore often understand public evaluations as accountability processes (see Mulgan 2003: 63). In addition, the voice of a reputable accountee with limited sanctioning powers may alert and activate hierarchical superiors. For 'weak' accountability arrangements to be effective in this sense, it is necessary that the outcomes are published or presented to superiors or in important policy networks. Or at least it is important that the accountee anticipates that this might happen. In those instances, relatively powerless forms of accountability can become influential because they operate 'in the shadow of hierarchy' (Scharpf 1997). As, as we will see, many horizontal accountability arrangements have limited formal sanctioning powers - they are found at the weaker end of the scale - they are quite dependent on published voice and voice in policy networks.

\section{Horizontal accountability}

Public administrations feature a wide variety of accountability arrangements. Different authors have made different categorisations of accountability. Romzek and Dubnick (1998) for instance distinguish between political, hierarchical, professional and legal accountability; and Behn (2001) between accountability for results, process and finances. In this paper, different accountability arrangements are categorized on the basis of the type of relationship between the accountor and the accountee. In traditional forms of accountability, a superior demands accountability from a subordinate. This is based on the principle of ownership (Mulgan 2003: 12) and is implicit in principal-agent approaches. Hence they can be understood as vertical forms of accountability. In order to categorize as a case of horizontal accountability, the accountee needs to be independent from both the agent and the principal. There is not a full principal-agent relationship between accountor and 
accountee. For semi-autonomous agencies, independent evaluators, boards of stakeholders or commissioners, journalists, interest groups and clients can all act as horizontal accountees. This is often based on the principle of affected rights and interests (Mulgan 2003: 13).

Numerous scholars have recently referred to horizontal accountability (Day and Klein 1987: 28; Sinclair 1995: 223; Scott 2000: 42; Goetz and Jenkins 2001: 363; Keohane 2002: 22; Mulgan 2003: 26; Bovens 2005). The concept is most strongly associated with the research of O'Donnell (1998; 2003. See also Kenney 2003). His conception of horizontal accountability is in the core similar to the one developed here, but differs in its implications. In the core he also asserts that horizontal accountability applies to non-hierarchical accountability. In its consequences, O'Donnell's research (see 1998: 117-9) deals with forms of accountability between the different constitutional powers of the state. He is particularly concerned with the question whether the legislative and the courts are in a position to effectively hold the executive to account. This paper also looks at non-hierarchical accountability, but looks at different accountors: O'Donnell focuses on the accountability of the executive, this paper at agencies. From the perspective of agencies, accountability to parliament would be a form of vertical accountability whereas it is horizontal in O'Donnell's perspective. Because of the similarity in the core of the argument this paper has chosen to make use of 'horizontal accountability' above other available (but narrower) concepts such as downward accountability (Verschuere et al 2006), citizen accountability (Paul 1992) or societal accountability (Smulovitz and Peruzzotti 2003).

If we summarize the argument so far, we come to the following criteria for horizontal accountability (Table 1). It is a purely analytical definition, that does not address the rich normative debate on accountability (see for normative discussions Romzek and Dubnick 1998; Behn 2001; Bovens et al 2008). The following elements define horizontal accountability arrangements.

Substitutes or complements?

The sum of all accountability arrangements of one agent may be called its accountability regime (Scott 2000: 55; Bovens et al 2008). The introduction of

Table 1 Elements of horizontal accountability

Elements

1. A relationship between an accountor and an accountee qualifies as a case of horizontal accountability when it is

a. Formalized

b. Acknowledged by the accountor

c. The accountee is independent from the hierarchical principal(s) of the accountee and the accountor

2. The accountability process begins with the Information phase, where the accountor is obliged to explain and justify his conduct;

3. after which the debating phase follows, in which the accountee poses questions, they engage in dialogue, and the accountee passes judgment ("voice").

4. Consequences: The accountor may face consequences through either

a. Formal sanctions, or

b. Informal consequences through published voice or voice in policy networks. 
horizontal accountability produces an accountability regime in which different accountees demand accountability, even though the ministry is still the most important. The prime evaluative question for additional arrangements is then how their role is defined in contrast or addition to ministerial responsibility. The question that needs to be answered is whether horizontal accountability is to be considered as an extension of ministerial responsibility or whether it is complementary and adds something new.

The literature tends to favour the second position. More specifically, authors have claimed that accountability to all sorts of stakeholders can be beneficial particularly from a learning perspective (Aucoin and Heintzman 2000; Behn 2001; Bovens et al 2008). Accountability creates feedback information with which public organisations may learn how to improve their conduct. Accountability forces power-holders to reflect upon their behaviour and this stimulates their learning capacities. 'Learning' in this respect means the 'revision of cognitions and beliefs as a result of the transformation or recoding of information based on the observation and interpretation of experience' (Hemerijck and Visser 2003: 4-5). Horizontal accountability is expected to produce feedback information on operations that is particularly supportive of first order, or single loop, learning processes (Argyris and Schön 1978). Additional accountability arrangements contribute to learning if they:

- Information phase: richness of information

- Debating phase: critical reflection

- Consequences: 'lessons' that lead to policy changes (Bovens et al 2008; Aucoin and Heintzman 2000: 52-54).

A minority of authors holds the opposite position that horizontal accountability should be judged from the question whether it enhances democratic control on the execution of public duties. This position implies that horizontal accountability is regarded as an extension of the democratic chain of controls on bureaucracies (Strøm 2000). From this perspective, the major evaluative questions are:

- Information and debating phases: horizontal accountability is informative to democratic accountees

- Consequences: horizontal accountability steers in a direction favoured by democratic principals.

The contributions of horizontal accountability arrangements in the Netherlands will now be assessed in order to investigate which of the above positions is most appropriate. Before proceeding, however, the research design and methods will be described in short.

\section{On the research}

The empirical research for this paper consists of the following steps. To begin with, an inventory was made of all the institutional arrangements of a subset of 82 Dutch agencies (see Schillemans 2007: 11-3 for selection). This lead to an inventory of 60 horizontal accountability arrangements (see Table 2). 
Table 2 Overview of accountability arrangements and research

\begin{tabular}{|c|c|c|c|c|c|}
\hline & $\begin{array}{l}\text { Boards of } \\
\text { stakeholders }\end{array}$ & $\begin{array}{l}\text { Boards of } \\
\text { commissioners }\end{array}$ & $\begin{array}{l}\text { Evaluation } \\
\text { ("visitation") }\end{array}$ & $\begin{array}{l}\text { Boards of } \\
\text { experts }\end{array}$ & Ombudsmen \\
\hline $\begin{array}{l}\text { Total } \\
\text { number of } \\
\text { agencies }\end{array}$ & 16 & 14 & 11 & 5 & 14 \\
\hline $\begin{array}{l}\text { Studied in } \\
\text { research? }\end{array}$ & Yes & & & No & \\
\hline $\begin{array}{l}\text { Studied } \\
\text { agencies }\end{array}$ & \multicolumn{5}{|c|}{$\begin{array}{l}\text { Accreditation Organisation of The Netherlands and Flanders } \\
\text { (NVAO); Agency for student grants (IBG); Air Traffic Control } \\
\text { (LVNL); Authority on vehicles (RDW); Cadastre and Public } \\
\text { Registers Agency (Kadaster); Central Funding of Institutions } \\
\text { Agency (CFI); Centre for Work and Income (CWI); Forest } \\
\text { Authority (Staatsbosbeheer); Netherlands Forensic Institute } \\
\text { (NFI); Netherlands Vaccine Institute (NVI); Pension and } \\
\text { Benefit Board (PUR); Social Security Agency (UWV); } \\
\text { Statistics Netherlands (CBS) }\end{array}$} \\
\hline Legal basis & Law (1 covenant) & Law & Covenant & & \\
\hline Focus & $\begin{array}{l}\text { Quality of output and } \\
\text { outcome }\end{array}$ & Good governance & $\begin{array}{l}\text { General } \\
\text { strategy/ } \\
\text { external } \\
\text { strategy }\end{array}$ & & \\
\hline $\begin{array}{l}\text { Frequency } \\
\text { of contact }\end{array}$ & Appr. 4 times a year & 4-7 meetings a year & $\begin{array}{l}\text { Once every } \\
4 \text { years }\end{array}$ & & \\
\hline $\begin{array}{l}\text { Types of } \\
\text { agencies }\end{array}$ & $\begin{array}{l}\text { Executive agencies; three in } \\
\text { domain social security; } \\
\text { two with partly scientific } \\
\text { tasks. }\end{array}$ & $\begin{array}{l}\text { Executive agencies; } \\
\text { some of them } \\
\text { operate close to } \\
\text { markets. }\end{array}$ & $\begin{array}{l}\text { Executive } \\
\text { agencies; } \\
\text { relatively } \\
\text { large }\end{array}$ & & \\
\hline
\end{tabular}

In the second step of the research, the accountability arrangements of 13 large agencies (a subset of the 60) were studied through document analysis and interviews. As accountability was defined as a communicative interaction between two parties, the document analysis aimed to reconstruct the content of this communication. This included an analysis of agenda's and minutes of official meetings, the most important official documents of the agencies, such as annual reports, strategic (mid term) plans, audits and evaluations and, policy documents of the ministries, reports and letters to parliament. Also unofficial minutes and documents were studied, when found to exist. And via internet, media-searches were conducted in order to find references to the horizontal accountability arrangements in press releases and media articles.

In the third place interviews were held with managers and senior officials of the agencies, members of executive boards, clients, other stakeholders and senior officials of parent-departments. In total 90 interviews were held with 70 respondents. The interviews were recorded and the verbatim text was typed. The reports of the interviews were then searched for all quotes that referred to the defining criteria of horizontal accountability (see Table 1), the influence on policy decisions and comments that refer to learning. The content, outcomes and influence of communicative interactions between accountors and accountees could thus be reconstructed. 
Following these steps, reconstructions have been made of the practices of horizontal accountability, and the impact of the mechanisms on agencies. Influence was acknowledged to exist when two independent respondents together with 'evidence' from formal documents, such as minutes of meetings, pointed to the same policy decision that was influenced by horizontal accountability.

The analysis allows for conclusions on specific arrangements, specific agencies or clusters of them. The descriptions hereafter will focus on overall conclusions, which was possible because the research found many remarkable similarities. The empirical part of this paper will now subsequently treat the three empirical questions of this paper: which horizontal accountability arrangements?, what contributions do they have in practice?, and how are we to understand their role in the accountability regime of agencies?

\section{Horizontal accountability arrangements}

Which mechanisms of horizontal accountability can be found at Dutch agencies? The criteria for horizontal accountability outlined above have been applied at the different external relations of a subset of 82 Dutch agencies. In total, 60 individual mechanisms were found. Grossly speaking five different mechanisms can be distinguished. First of all, boards of stakeholders (16 agencies). These boards are usually made up of organizations that represent individual or corporate clients. In some instances they represent real citizens that are affected by the policies of the agency. Secondly, boards of commissioners (14). These boards are made up of members with a wealth of experience in the policy area of the agency. They are appointed by the ministry but they do not have to account for their oversight (or lack thereof) to the minister. Thirdly, boards of experts (5). These boards are all found at agencies with complex, professional tasks, mostly in specialized research. Fourthly, there are forms of horizontal accountability to independent evaluation committees ('visitation' - 11). The focus of the evaluations is responsiveness to clients and the overall external strategies of agencies. The evaluation reports are always published and also sent to the minister and members of parliament. Finally there are agencies with a special ombudsman or independent complaints office (14).

The above mechanisms were all found to fulfil the criteria of our definition of horizontal accountability.

Criterion $1 a$ points to the formalization of the relationship between accountor (agency) and accountee. The three different types of boards all have a legal basis. Most of them are instituted in the laws that establish and regulate the (relative) autonomy of the agencies. The same applies to most of the ombudsmen and independent complaint offices. The independent evaluations (visitations), however, have a basis in a covenant between likeminded agencies. The different regulations stipulate, in many different ways, that the accountees have the task to keep a watchful eye on the strategic policy decisions of agencies. They are to operate as a check on the discretion of agencies by monitoring their behavior from the perspectives of stakeholders (stakeholder councils; "visitations"), expert knowledge (boards of experts), good governance (boards of commissioners) or due process (ombudsmen). In order to fulfill their role, the different accountees are entitled to all 
the information they require for their task (right to information). In some cases (some boards of commissioners), they have access to all documents, offices, and personnel in order to justify their need for information. Also, they are to meet with the management of the agency on a regular basis to discuss its conduct (debating phase). And they are expected to pass judgment on the conduct of the agencies. This judgment is published in public documents and is made available to political principals; their 'voice' thus appears in public and in important policy networks.

With the exception of the boards of commissioners, these arrangements have only limited sanctioning powers. This means that the different 'horizontal accountees' can not enforce their will upon the agencies. In order to influence the (future) decisions of the agencies, they mostly have to rely on the persuasive qualities of their voice or they can hope that their voice works through the shadow of hierarchy. Their position as accountees is based on a) legal status, b) duty to give judgment on all strategic policy choices, c) public character of their judgements (criterion $4 b$ ) and d) personal networks with important external policy actors, such as ministers, political parties, ministries or issue organisations (criterion $4 \mathrm{~b}$ ).

Criterion $1 b$ stresses the informal and social aspects of accountability relationships. During the research, all interviewed managers and senior staff were asked in open questions whether or not they felt to have an obligation to account for their conduct to the boards and in the evaluation process. Around $85 \%$ of the respondents felt that 'accountability' was indeed a part their relationship. However, the respondents also indicated that it was a form of accountability that differed in nature from vertical accountability towards the ministry. Explicitly or implicitly they then referred to the fact that the horizontal mechanisms mostly lack strong corrective measures. As one respondent noted "We provide information and reasons for our choices. But there is less of a need to defend ourselves".

Criterion $1 c$ stresses that accountees must be independent from ministry as well as agency in order to be seen as 'horizontal'. Formally, this is the case for all of the mechanisms. The members of the boards stand outside of the principal-agent relationship. The laws clearly indicate that they are to act "without seeking or accepting instructions". They have a personal responsibility for their role, something which for instance is accentuated for some boards, where the members bear a personal liability for their choices. Normally, boards select members through cooptation and they thus decide on their own memberships (even though this often needs the approval of the minister). In practice however, independence is a more complex issue. For one thing, the members of boards are recruited from policy networks where they are bound to know and encounter the minister or senior departmental civil servants. In addition, the different accountees need support from the agencies in order to attain the information they need. They are therefore assisted by secretariats with employees from the agency. This may in practice compromise their independence. As one of the secretaries of a board notes: "It is a complex issue, sometimes. I work for the board, but there are of course people within the agency who are my bosses". So in practice, independence is checked by policy networks (recruitment) on the one side and information demands (secretariats) that tie accountees to the accountors on the other. Individual members therefore indicate that they have to maneuver between personal integrity, solidarity with the agency and affinity with the minister and the parent department. 
The other criteria of horizontal accountability apply to the practices of the accountability processes. This will be treated in the next section of this paper.

\section{Horizontal accountability-in-action}

Three of the aforementioned types of horizontal accountability will be covered in this section: boards of commissioners, boards of stakeholders and 'visitations' (independent evaluations). The rationale for this selection is that they were found to operate in many similar ways - even though there are numerous formal differences. Also, they stand for three quarters of the total number of mechanisms that were found. The analysis is based on the practices that were reconstructed in the qualitative analysis. The 'story' is organized according to the criteria from our definition: the information phase (criterion 2), the debating phase (criterion 3) and the consequences (criterion $4 \mathrm{a}$ and $4 \mathrm{~b}$ ).

\section{Criterion 2: information phase}

The information phase of horizontal accountability processes generally focuses on major strategic policy issues, such as budgets, tariffs, quality standards and political developments in the field. The different accountees are mostly informed about the conduct of the agencies through the same documents that are also presented to the principal. These documents generally cover the most important strategic aspects of the activities of agencies. Documents such as annual reports, mid-term strategic plans and all documents about services are discussed with the ministry, board of commissioners, board of stakeholders, and they are embodied in the visitation procedure. The minutes of meetings show that the different boards comment and give advise on documents such as mid term strategic plans, plans to reorganize the organization, the annual report, new tariffs, and relevant legal and political developments.

The (re-)use of the same information in different accountability processes is generally considered as a positive feature, or at least as something very practical. As one respondent notes: 'It is true that we discuss the same documents with the ministry, the board of commissioners and the board of stakeholders. Luckily, I should add. Otherwise it would be an enormous task providing all the information'.

Most respondents indicate that the topics that are covered in the information phase can be loosely divided into two categories. One respondent indicates that the 'inner world' of the general strategy of the agency is the first important issue. This also regards issues such as communication with customers and quality standards. The second major issue is, according to the same respondent, the 'outer world' of relationships with political principals and societal stakeholders. This last finding is a little surprising, as they formally have to contribute to the quality of services and stability of the agencies (the inner world). In practice however, all of these horizontal accountees display a keen interest in the politico-strategic issues of the outer world with which the agencies have to deal. Boards therefore demand to be informed about all major external and political developments. 
It is important to note that there is a more or less supply-driven information provision in the information phase that distinguishes horizontal accountability from traditional forms of vertical accountability. In vertical accountability, agencies have to provide government, inspection services, Ombudsmen, Auditor-General and judges with all the information they require. The exchange of information is usually driven by the demands of the accountees. In horizontal arrangements, the accountees take more passive stance. They concentrate on the "drill of the annual planning and control cycle", as one respondent noted. The accountees are more dependent on the information that is provided to them because they usually have less time at their disposal and have limited knowledge of what information is available. There is an information-asymmetry between accountor and accountee that stems from the fact that the organisation of course knows a lot more about its own operations than the accountees do. When asked, none of the members of the different boards found this problematic. They were convinced that they received all the information they needed, because they fostered friendly relationships with the managers of the agencies.

\section{Criterion 3: debating phase}

In the debating phase of horizontal accountability, the dialogue between accountors and accountees generally covers the most important aspects of the 'inner world' and 'outer world' of the agencies. Most respondents describe the tone of their dialogue as 'cordial' and 'friendly'. All accountees have the dual task of assisting and advising the organisation on future action and evaluating past performance. In practice, the former issue often prevails. Accountees do not concentrate their scrutiny on breaches of performance standards. Rather, their focus is reflective and aimed at future improvements. As different respondents indicate, accountees tend to ask: 'what can we learn from this?' And another respondent adds: 'We prefer to operate in the realm where actions are still to be taken'.

When asked, most respondents describe the role of the different boards and visitations in terms that clearly suggest'reflection'. 'Their role in practice is to look ahead', one observer notes. Others add that they operate as 'sparring partners' to management over major strategic issues, that they abound in posing 'difficult questions' on new policy decisions and that their role is to 'enhance critical reflection'.

This cooperative and reflective mode of operation is enhanced by the interests of both parties. Members of boards and visitation committees have to deal with information-asymmetry. The agencies are large bureaucracies with hundreds or thousands of employees. They perform complex tasks in often turbulent political contexts. Members of boards and visitation committees simply do not have the time to penetrate into all of the issues involved. Self-estimations of invested time run from 50 to a 100 available annual hours. In addition, they are supported by a small staff of employees of the agency. In this context, a reflective and cooperative mode of operation is rational. Some members of boards reflect upon this openly. They indicate that the quality of the relationship also has strategic benefits, because: "you simply receive more information" and: "we attain more this way". 
Fostering a more or less cooperative accountability relationship is also beneficial to the other party: the managers of the agencies. They indicate that the different members of the boards are all connected to relevant outside constituencies. Members of boards are sometimes seen as interlocutors to the minister, they have networks in important bureaucratic circles or they are connected to the strongest societal organisations and pressure groups. It is in part against this background that managers explicitly indicate that is important to develop a positive relationship in horizontal accountability. They indicate that this could 'enhance their reputation' and that the members of boards may 'serve as ambassadors to our cause'.

However, irrespective of the motives of accountors and accountees for developing a cooperative and reflective relationship, this reflection-enhancing role strengthens a bond of trust between accountor and accountee. This creates a form of accountability wherein the social distance between accountor and accountee decreases. This is what Roberts calls a form of face-to-face accountability that can have socializing effects (Roberts 2001: 1567). The repeated dialogue between the two parties fosters trust and cooperation and this may challenge explicit or implicit policy assumptions. Over time, their repeated dialogue stimulates learning processes. In accordance with this view it is clear that the different accountees all aim to formulate lessons for future improvements.

In comparison to traditional forms of accountability, it is noteworthy that the horizontal accountability processes evolve in relatively safe settings. As one director of an agency notes: 'It is not similar to meetings with the ministry, where I always go with a slightly increased level of adrenaline. It's not like that when I meet with the board'. However, the dialogue is not devoid of tension either. Both parties acknowledge - and notify this explicitly and usually without being asked directly in the interviews - that the principal is a silent listener to their discussions. In some instances, minutes of their meetings are sent to the minister and screened by his civil servants. As one departmental respondent puts it: 'I always listen carefully to what the board has to say, because you know that the opinions [of board members] are likely to recur later on'. In other instances, members of boards sometimes meet formally or informally with the minister or senior ministerial officials. In these circumstances, boards can serve as important 'ambassadors' to the cause of the agency, or, in a less positive fashion, they can function as a 'snitch', as another manager feared. And in still other instances, the outcomes of horizontal accountability can and will be used by departmental personnel as monitoring information. The ambiguity of the possible consequences adds tension to the dialogue between accountor and accountee that circumvents the perils of a collusion of interest.

\section{Criterion 4: consequences}

Processes of horizontal accountability can have different sorts of consequences for agencies. It may directly influence policy decisions and may also work indirectly, when the judgments and voice of the accountees activates other parties, such as the ministry, a regulator or the media. And accountees may use formal sanctions, when available. The different sorts of consequences were found in the investigated agencies. In the observed cases there was some direct influence of horizontal 
accountability and there was some additional influence through the interaction with the 'shadow of hierarchy'.

\section{Criterion 4a: formal sanctions}

The only mechanisms for horizontal accountability with strong formal sanctions are (most of the) boards of commissioners. Important powers that normally reside with the minister have been partially transferred to these boards. These include budgetary powers, the appointment and discharge of management, tariffs and the possibility to lay down binding directives for operations. Boards address all major operations and organizational strategies, just as boards of commissioners do in the 'two tier system' of the private sector.

During the interviews, managers and members of boards were asked how these formal sanctions were used. The answers generally consisted off three parts. To begin with, most of the respondents were able to point out which formal sanctions were available to the board. This indicates that the sanctions were indeed important. However, none of the respondents could remember a situation in which they were actually used. The formal documents also did not uncover situations where sanctions were applied. The respondents explained that the cooperative attitude of managements decreased the need to use formal sanctions. In addition, they also indicated that the boards hardly ever promoted policies that differed strongly from the existing policies. As one respondent noted: "they mostly strengthen what we already do, the bandwidth of their views is not radically different". This is a second reason why formal sanctions are not used.

The fact that there are little formal sanctions and that the available sanctions are not used might suggest that horizontal accountability had no influence on the policies of the agencies. This suggestion is not correct. The research showed many policy decisions that were influenced through horizontal accountability. Processes of horizontal accountability generally have a clear, but somewhat modest, influence on the decisions of agencies. For most of the agencies that were examined, it was possible to find a number of specific decisions that were influenced by horizontal accountability. Influence was acknowledged to exist when two independent respondents together with 'evidence' from formal documents, such as minutes of meetings, pointed in the same direction. For boards, most instances of influence concerned improvements to systems of management or the relationship with the ministry. For boards of stakeholders, instances of influence were mostly concerned with specific aspects of services, and particularly communications with clients. The influence of visitations is primarily directed towards transparency and responsiveness. Table 3 presents an overview of decisions and issues that were found to be influenced by horizontal accountability.

The length of this table perhaps falsely suggests that horizontal accountability was found to have a very strong direct influence on the decisions of agencies. But that is not the case. Most listed items are decisions that can be taken without further consequences for the overall policies of the agency. They are important to the system or aspects of quality care, but can not be considered as major strategic changes. Horizontal accountability was then found to have a clear influence on the agenciesbut also clearly less influence than hierarchical powers with stronger authorities. The 
Table 3 Decisions that were influence by horizontal accountability

\begin{tabular}{|c|c|c|}
\hline \multicolumn{3}{|l|}{ Decisions } \\
\hline $\begin{array}{l}\text { New chapter is added to } \\
\text { long term strategic plan }\end{array}$ & Analysis of media-sensitive issues & $\begin{array}{l}\text { Improvements in accessibility of } \\
\text { telephone services }\end{array}$ \\
\hline $\begin{array}{l}\text { Changes in policies for } \\
\text { whistle blowers }\end{array}$ & Consultation with unions & $\begin{array}{l}\text { Changes in format of research on } \\
\text { customer satisfaction }\end{array}$ \\
\hline $\begin{array}{l}\text { External accountant is } \\
\text { contacted }\end{array}$ & Changes in ICT-policies & $\begin{array}{l}\text { Changes in regulation of board of } \\
\text { stakeholders }\end{array}$ \\
\hline Governance-code & Veto on a specific estate-acquisition & Increased organizational transparancy \\
\hline $\begin{array}{l}\text { Assessment of quality of } \\
\text { scientific outputs }\end{array}$ & $\begin{array}{l}\text { Termination of an 'expensive' and } \\
\text { voluntary service }\end{array}$ & $\begin{array}{l}\text { Boards of commissioners and } \\
\text { stakeholders were connected with } \\
\text { each other }\end{array}$ \\
\hline $\begin{array}{l}\text { Investigation in added } \\
\text { value of organisation }\end{array}$ & $\begin{array}{l}\text { Many changes in brochures, } \\
\text { communications and formal letters } \\
\text { to clients }\end{array}$ & $\begin{array}{l}\text { Board of stakeholders was connected } \\
\text { to organisations of local } \\
\text { stakeholders }\end{array}$ \\
\hline Inventory of real estate & $\begin{array}{l}\text { A bureau for customer services is set } \\
\text { up }\end{array}$ & $\begin{array}{l}\text { Changes in policies regarding } \\
\text { integrity }\end{array}$ \\
\hline $\begin{array}{l}\text { Check on bureau-costs in } \\
\text { international } \\
\text { benchmark }\end{array}$ & $\begin{array}{l}\text { Clients who were negatively affected } \\
\text { by conflicting regulations were } \\
\text { helped }\end{array}$ & \\
\hline \multicolumn{3}{|c|}{$\begin{array}{l}\text { Communication } \\
\text { magazine }\end{array}$} \\
\hline $\begin{array}{l}\text { A new and improved } \\
\text { complaints policy }\end{array}$ & & \\
\hline
\end{tabular}

fact, however, that all mechanisms at least did have some impact on agency-policies, even without strong formal sanctions, can be understood through the 'strength' of published voice and the policy networks of the different members.

Criterion 4b: informal consequences through published voice and voice in policy networks

Horizontal accountability was found to have indirect consequences by activating the ministry and the minister-or by the anticipation that this might happen. All respondents indicated that they were aware of the fact that hierarchical actors might and often did 'listen' to the dialogue between agencies and the different boards. Departmental respondents stated that they scanned agenda's, minutes, reports and other evolving documents in order to trace 'new developments', 'risks' or 'unwanted policy interpretations'. Particularly the visitations showed several of these informal consequences. This is the case because the resulting report is often used as input for vertical accountability. Visitations are used by ministerial departments as forms of fire alarm monitoring (McCubbins and Schwartz 1986). The visitation procedure is highly public. The reports are published and the press write about the outcomes. This is possible, because the process creates new and often highly informative information on the agencies. This is due to the outspoken style of the evaluation committee, the level of new information that is brought out through the selfevaluations and the clear-cut evaluative perspective that is used. Through this all, the process is always informative to outsiders. The visitation procedure therefore has started to play a role that extends the confines of the relationship between agency and visitation committee. Some reports have been discussed in the ministries. Some 
ministers have drafted formal reactions and often it has lead to discussions between parent-department and agency about specific outcomes. In one of the cases, the permanent secretary of the parent-department did an unsuccessful attempt to prevent the publication of the report. In another case it was agreed that the ministry was to receive the draft-report before publication, which left some room for intervention. The visitation thus adds to the monitoring capacity of the principal. Also, the voice of the boards in particular was sometimes taken over by the ministry. One example is where a board of stakeholders issues a public advice on the tariffs of an agency that is subsequently adopted by the minister.

More important however than the question whether or not the ministry acts upon the signals from horizontal accountability is the insight that the agencies were found to anticipate this. Given that the boards are potential ambassadors of the organisation, negative voice by boards in public or policy networks is clearly unwanted. Ministerial respondents point out that this is exactly what they expect horizontal accountability to accomplish. And furthermore, should for some reason a negative voice evolve, they would certainly act upon it. As one respondent puts it: "I assume that we would consider a negative voice from the board as a rather serious signal. Given the fact that the organisation will try to prevent this to occur (...) so if it does occur, then it needs to be taken really seriously".

The ministerial respondents thus correctly expect that agencies try to prevent negative conclusions in horizontal accountability. Loss of reputation and organizational legitimacy are important motivational factors in this respect. As Verhoest et al (2007: 487) note, the possibility of sanctions creates a political pressure to adapt policies and this can lead to innovative behaviour. Managers foster the legitimacy of their organisation. They anticipate that negative news may lead to negative future consequences.

Horizontal accountability is important in respect to the legitimacy and reputation of agencies. Through horizontal accountability, agencies are able to build a coalition of supporters. Carpenter (2001) showed how agencies actively look for support for their policies and try to build networks in different important arenas. In the long run, it is important that the agency has a political multiplicity, which means that it draws support from a variety of proponents. This is a safer situation for the agency than the situation where an agency is fully dependent on a single department, political party, dominant interest group or segment of society. Horizontal accountability can be used to build long-term constituencies. It can contribute to reputational uniqueness, which means that the agency can demonstrate that it possesses skills and expertise that no other agency or political actor can provide. Positive voice by a reputable third party, boards or a visitation committee, is favourable from this perspective. Their support strengthens the reputation of the agency and increases trust by political principals.

\section{Discussion: learning in the shadow of hierarchy}

In the first part of this paper it was indicated that horizontal accountability could either be seen as a substitute for (or extension of) ministerial accountability or as complement that stimulates learning. Now that horizontal accountability-in-action has been described, it is time to evaluate our findings. As noted before, most 
commentators on new accountability mechanisms stress their relevance to organizational learning, not the possibilities for ministerial control. The discussion of horizontal-accountability-in-action in the preceding part clearly supports this estimation.

There are several reasons why horizontal accountability - as it was found to work-can not be seen as a potential substitute for ministerial responsibility. To begin with, horizontal accountees do not act as deputies for the minister. None of the board members referred to the ministry when asked about their roles. They do not exert control on behalf of the ministry. As one of them stated firmly: "I am not here to help the minister". On many occasions quite the contrary happens when boards (try to) direct the agency in opposing directions. Furthermore, these new mechanisms do not create an alternative form of accountability to democratically legitimized accountees. Particularly the representatives of stakeholders, who carry the highest 'democratic promise', experience legitimacy problems. In some occasions the representatives voiced opinions that conflict with those of the clients they are supposed to represent. In some other instances, the boards had severe difficulties finding 'real' clients who were willing to participate. This leads to a situation that one observer sarcastically describes as: "we seem to be stuck with professional clients only'.

For these reasons, horizontal accountability must be considered as something that differs from the democratic control through ministerial responsibility. What horizontal accountability adds, however, is that it stimulates the learning capacity of agencies. The impact on learning starts in the information phase, where the additional mechanisms create richness of information and new insights for the people concerned. In the debating phase, accountors and accountees engage in reflective dialogues aimed at policy improvements. The accountees do not use their judgement as instruments of control. Rather, they try to formulate, as one respondent noted: "operational lessons that help the agencies to improve". These are socializing forms of accountability that stimulate reflection and may over time lead to improved services. The added value of these mechanisms is that they engage the insights and knowledge of experienced peers or representatives of stakeholders. It is a form of $360^{\circ}$-accountability, as described by Behn (2001). Where stakeholders and experts reflect on the policies of the agencies, this can be seen as feedback effects. Their judgments are based on interests and priorities that differ from those of the ministry. It is particularly noticeable that they are less driven by short term political considerations and are more concerned with the quality of service over time. In that respect, horizontal accountability is complementary to vertical control.

The learning processes through horizontal accountability take place in the 'shadow of hierarchy' (Scharpf 1997: 202). Scharpf has pointed out how ministers influence decentralized decision-making between different government departments or between employers and labour unions, without active personal interference and even without knowing they do. This capacity stems from their ability to ratify the agreements that decentralised parties agree upon. As the other parties know their outcomes will or could be scrutinized by the minister, they will try to anticipate his reactions. His anticipated veto points and preferences condition the possible outcomes and actions of the involved parties. This way, the minister as an absent party can nevertheless influence the processes and outcomes of horizontal 丝 Springer 
exchanges. The same principle seems to apply to processes of horizontal accountability. The shadow of the principal is cast on the relatively reciprocal interactions between agencies and their boards and visitation committees. The shadow of hierarchy strengthens and constrains these new arrangements.

The shadow of hierarchy strengthens horizontal accountability, as the relatively 'weak' mechanisms gain in influence through their connection with hierarchical powers via published voice and their voice in policy networks. The respondents from agencies all point out that they are aware of the possibility that the horizontal interactions may have an impact-for better and for worse-in their vertical relations. In the words of one respondent: "The members of the board are potential ambassadors in important policy circles where we are not always present ourselves." This potential connection with policy networks brings a productive tension to their dialogue, leads to some anticipative reactions by the agencies (in the sense of Friedrich 1963: 200-4) and in general stimulates the agencies to treat board members and visitations with much respect. Through this connection to the shadow of hierarchy, the relatively powerless horizontal accountability arrangements attain influence on many policy decisions of agencies (see Table 3).

However, the shadow of hierarchy also constrains the influence of horizontal accountability. In the information phase, the same topics and issues are brought to the attention of departmental overseers as well as to boards and visitation committees. In vertical and horizontal accountability, the same issues are thus treated, albeit from different perspectives. The respondents are very clear when asked which of the different accountees is most influential on the same topics: the parent department of course. The documentation that was studied points in the same direction. This should not come as a surprise, as it is a logical consequence of the fact that the investigated mechanisms all ascribe very limited sanctioning authorities to the accountees. The possibilities to influence agencies directly are therefore restricted. In addition, horizontal accountability is more of a cooperative dialogue with management and is generally supportive of existing strategic choices. Boards and councils use their position primarily to strengthen and improve the existing policies, they have little inclination to change them in more fundamental ways as ministries and politicians on the other hand repeatedly attempt to.

In situations of conflicting opinions between vertical and horizontal accountability, the former naturally 'wins'. In one case an agency was more or less forced by the ministry to make a costly investment in real estate, even though it is formally its own authority to make these decisions. The board of commissioners strongly opposed this investment, as it was understood to be rather risky. The executive management agreed with their assessment but indicated that it was not able to resist the ministry.

The possibilities of influence through horizontal accountability are constrained by vertical accountability. If ministerial oversight is tight, the opportunities for horizontal accountability to gain influence evaporate. This happened for instance during the research when one agency became subject of a policy crisis that drew close attention of the media, the ministry and politicians. During the crisis, which lasted for about 6 months, the existing boards became more or less superfluous. They had no impact on the proceedings or on the agency, as all of the respondents note. And another agency suffers strong hierarchical controls on all budgetary decisions. In effect, the board of commissioners has decided not to focus its 
oversight too strongly on the budget. A member of the board explains: "The annual budget? ? We have little options there. The department and the agency spell out all the details in advance; it's like a moving train. So we do talk about the budget, but not in much detail."

In situations of tight vertical control, horizontal accountability has little effects and could be seen as basically symbolic. The arrangements are added to the accountability regime because they create the suggestion that the agencies take the interests and opinions of stakeholders into account. But the extensive hierarchical controls leave no serious room for influence. Particularly for the Dutch social security agencies (UWV and CWI) this symbolic interpretation of horizontal accountability comes to the fore. They are confronted with different councils of clients with a high normative value because they should stimulate responsiveness to clients and improvements in services. But in effect, they have very little influence on the policies. As one critical departmental respondent notes: "You know, in political debates, we all say that these client councils are of utmost importance. But to be honest: I don't see any real effects".

For many of the other agencies, however, the distance between parent-department and agency is larger and the arrangements have real effects. The symbolic interpretation of horizontal accountability is only appropriate for a limited number of cases. For the majority of cases, the relative distance of the parent-department creates the room in which horizontal accountability stimulates learning processes. The research showed that these new accountability arrangements have added value because they are complementary to traditional accountability: they stand out by their focus on reflective dialogue and learning.

Acknowledgments Earlier versions of this paper were presented at the annual conferences of the European Group of Public Administration (September 2007) and the Netherlands Institute of Governance (November 2007). The author is grateful to the organizers and the participants at both occasions for helpful comments.

Open Access This article is distributed under the terms of the Creative Commons Attribution Noncommercial License which permits any noncommercial use, distribution, and reproduction in any medium, provided the original author(s) and source are credited.

\section{References}

Argyris, C., \& Schön, D. 1978. Organisational learning: A theory of action perspective. Addison Wesley: Reading Mass.

Aucoin, P., \& Heintzman, R. 2000. The dialectics of accountability for performance in public management reform. International Review of Administrative Sciences, 66(1): 45-55.

Barberis, P. 1998. The new public management and a new accountability. Public Administration, 76: 451470.

Behn, R. D. 2001. Rethinking democratic accountability. Washington D.C.: Brookings Institution Press.

Besley, T., \& Ghatak, M. 2003. Incentives, choice and accountability in the provision of public services. Oxford Review of Economic Policy, 19: 235-249.

Bovens, M. 2005. Public accountability. In Ferlie, E., Lynne, L., \& Pollitt, C. (Eds.). The Oxford handbook of public management: 182-208. Oxford: Oxford University Press..

Bovens, M., Schillemans, T., \& 't Hart, P. 2008. Does public accountability work an assessment tool. Public Administration, 86(1): 225-242. 
Braithwaite, J. 1999. Accountability and governance under the New Regulatory State. Australian Journal of Public Administration, 58: 90-93.

Broadbent, J., Dietrich, M., \& Laughlin, R. 1996. The development of principal-agent, contracting and accountability relationships in the public sector. Conceptual and cultural problems. Critical Perspectives on Accounting, 7: 259-284.

Carpenter, D. C. 2001. The forging of bureaucratic autonomy: Reputations, networks, and policy innovation in executive agencies: 1862-1928. New jersey: Princeton University Press.

Day, P., \& Klein, R. 1987. Accountabilities. Five public services. London: Tavistock.

Dubnick, M. J. 2005. Seeking salvation for accountability. Paper presented at the Accountable Governance International research Colloquium at the Institute of Governance, Queen's University Belfast.

Dunn, D. D. 1999. Mixing elected and non-elected officials in democratic policy making: fundamentals of accountability and responsibility. In Przeworski, A., Stokes, S., \& Manin, B. (Eds.). Democracy, accountability, and representation: 297-325. Cambridge: Cambridge University Press.

Flinders, M. 2001. The politics of accountability in the modern state. Brulington: Ashgate.

Friedrich, C. A. 1963. Man and his government. An empirical theory of politics. New York: McGraw-Hill.

Goetz, A. M., \& Jenkins, R. 2001. Hybrid forms of accountability. Citizen engagement in institutions of public-sector oversight in India. Public Management Review, 3: 363-383.

Harlow, C., \& Rawlings, R. 2007. Promoting accountability in multilevel governance: A network approach. European Law Journal, 14(4): 542-562.

Hemerijck, A., \& Visser, J. 2003. Policy learning in European welfare states. Florence: EU-Center.

Hood, C., Scott, O., James, O., Jones, G., \& Travers, T. 1999. Regulation inside government: Wastewatchers, quality police, and sleazebusters. Oxford: Oxford University Press.

Kenney, C. D. 2003. Horizontal accountability. Concepts and conflicts. In Mainwaring, S., \& Welna, C. (Eds.). Democratic accountability in Latin America: 55-76. Oxford: Oxford University Press.

Keohane, R. O. 2002. Political accountability. Paper presented at the 'Conference on Delegation to International Organizations. Utah: Park City.

Lerner, J. S., \& Tetlock, P. E. 1999. Accounting for the effects of accountability. Psychological Bulletin, 125(2): 255-275.

McCandless, H. E. 2001. A citizen's guide to public accountability. Changing the relationship between citizens and authorities. Trafford: Victoria BC.

McCubbins, M. D., \& Schwartz, T. 1986. Congressional oversight overlooked: Police patrols versus fire alarms. American Journal of Political Science, 28(1): 165-179.

Mulgan, R. 2003. Holding power to account. Accountability in modern democracies. New York: MacMillan Palgrave.

O’Donnell, G. 1998. Horizontal accountability in new democracies. Journal of Democracy, 9(3): 112-126.

O'Donnell, G. 2003. Horizontal accountability. The legal institutionalization of mistrust. In Mainwaring, S., \& Welna, C. (Eds.). Democratic accountability in Latin America: 34-54. Oxford: Oxford University Press.

Orbuch, T. L. 1997. People's accounts count. The sociology of accounts. Annual review of sociology, 23: $455-478$.

Paul, S. 1992. Accountability in public services. Exit, voice and control. World Development, 20: 10471060 .

Pollitt, C. 2003. The essential public manager. London: Open university press/McGraw-Hill.

Pollitt, C., Talbot, C., Caulfield, J., \& Smullen, A. 2004. Agencies. How governments do things through semi autonomous organisations. Basingstoke: Palgrave Macmillan.

Przeworski, A., Stokes, S., \& Manin, B. 1999. Democracy, accountability, and representation. Cambridge: Cambridge University Press.

Roberts, J. 2001. Trust and control in Anglo-American systems of corporate governance. The individualising and socialising effects of processes of accountability. Human Relations, 54: 1547-1572.

Romzek, B. S., \& Dubnick, M. J. 1998. Accountability.. In Shafritz, J. M. (Ed.). International encyclopedia of public policy and administration, vol. 1 A-C. Boulder: Westview.

Scharpf, F. W. 1997. Games real actors play. Actor centered institutionalism in policy research. Boulder: Westview.

Schillemans, T. 2007. Verantwoording in de schaduw van de macht. Horizontale verantwoording bij zelfstandige uitvoeringsorganisaties. Den Haag: Lemma.

Scott, C. 2000. Accountability in the regulatory state. Journal of Law and Society, 27: 38-60.

Sinclair, S. 1995. The chameleon of accountability. Forms and discourses. Accounting. Organizations and Society, 20(2/3): 219-237. 
Smulovitz, C., \& Peruzzotti, E. 2003. Societal and horizontal controls. Two cases of a fruitful relationship. In Mainwaring, S., \& Welna, C. (Eds.). Democratic accountability in Latin America: 309-331. Oxford: Oxford University Press.

Strøm, K. 2000. Delegation and accountability in parliamentary democracies. European Journal of Political Research, 37: 261-289.

Thatcher, M., \& Stone Sweet, A. 2002. Theory and practice of delegation to non-majoritarian institutions. West European Politics, 25(1): 1-22.

Van Thiel, S. 2000. Quangocratization: Trends, causes, consequences. Utrecht: ICS.

Verhoest, K., Verschuere, B., \& Bouckaert, G. 2007. Pressure, legitimacy, and innovative behavior by public organizations. Governance, 20(3): 469-497.

Verschuere, B., Verhoest, K., Meyers, F., \& Peters, B. G. 2006. Accountability and accountability arrangements in public agencies. In Christensen, T., \& Lægreid, P. (Eds.). Autonomy and regulation: Coping with agencies in the modern state: 268-300. Cheltenham: Edward Elgar.

Thomas Schillemans, born in 1972, has a Ph.D. in Public Administration (Utrecht University, 2007). He is an Assistant Professor at the Utrecht School of Governance, Utrecht University. He was previously associated with the universities of Maastricht and Tilburg and for the Dutch Council for Social Development. His current research interests center around the concept of accountability, the influence of external parties on public organizations and the role of the media in relation to executive agencies. 